Journal of Advanced Research in Fluid Mechanics and Thermal Sciences

\title{
Investigation of Flow Pattern and Void Fraction of Air and Low Surface Tension Liquid in A $30^{\circ}$ Inclined Small Pipe
}

\author{
Sudarja ${ }^{1, *}$, Sukamta $^{1}$, Fauzan Saputra ${ }^{1}$ \\ 1 Department of Mechanical Engineering, Universitas Muhammadiyah Yogyakarta, Yogyakarta 55183, Indonesia
}

ARTICLE INFO $\quad$ ABSTRACT

\section{Article history:}

Received 30 September 2020

Received in revised form 23 April 2021

Accepted 2 May 2021

Available online 16 June 2021

\section{Keywords:}

Two-phase flow; small channel; liquid surface tension; flow pattern; void fraction

\begin{abstract}
Two-phase flow in the mini pipe is applied in wide fields. The most common of twophase flow is a couple of gas and liquid. The essential properties of the liquid are density, viscosity, and surface tension. There are many variations of the flow direction, horizontal, incline, and vertical, in terms of orientation. The two-phase investigation of flow pattern and void fraction of air and low surface tension liquid in a $30^{\circ}$ inclined small pipe has been carried out. Dry air was used as a gas phase, while the liquid was the mixture solution of distilled water and $3 \%$ (by volume) of butanol. Butanol addition aimed to decrease the surface tension, which became 42.9 millinewton/meter, instead of $71 \mathrm{mN} / \mathrm{m}$ when using distilled water. The test section was a $130 \mathrm{~mm}$ length, $1.6 \mathrm{~mm}$ inner diameter circular glass pipe. The rig used was equipped with the air compressor, pressure tank, high-speed camera, liquid flow meter, and gas flow meter. The liquid was fed to the test section by the pressurized tank, instead of directly pumped, to avoid pulsation. Ranges of gas and liquid superficial velocities were $0.025-66.3 \mathrm{~m} / \mathrm{s}$ and $0.033-4,935 \mathrm{~m} / \mathrm{s}$, respectively. Flow patterns were obtained from the captured highspeed video. Meanwhile, the void fractions were acquired by image processing of the video. As a result, five distinctive flow patterns were observed: plug, slug-annular, churn, bubbly, and annular. The separated flow was absent. The change of the liquid surface tension affected the shifting of some transition boundary lines in the flow pattern map. The transition line between slug-annular and annular against churn flow was shifted to the lower side or toward lower $J_{L}$ when the liquid surface tension decreased. In short, the churn flow was easier to be formed when the liquid surface tension was lower.
\end{abstract}

\section{Introduction}

As stated by Kawahara et al., [1], two-phase flow in the mini pipe has been applied in broad fields, such as in microelectronic circuits, aerospace and micro heat pipes, and bioengineering applications. Other applications are cooling high-density multi-chip modules in supercomputers, high-flux heat exchangers in aerospace systems, cryogenic cooling systems in satellites, high-powered X-ray, and other diagnostic devices [2]. Two-phase flow patterns were studied for various combinations of flow conditions, working fluids, and channel dimensions. Some of them are depicted in Table 1.

\footnotetext{
* Corresponding author.

E-mail address: sudarja@umy.ac.id
}

https://doi.org/10.37934/arfmts.83.2.7383 
Table 1

Studies of two-phase flow pattern in mini and micro-channels in the literature

\begin{tabular}{|c|c|c|c|}
\hline Authors & Channel configurations & Working Fluids & Flow patterns observed \\
\hline Triplett et al., [3] & $\begin{array}{l}\text { Circular } \\
\text { Dc = } 1.1 \text { and } 1.45 \mathrm{~mm} \\
\text { Semi-Triangular } \\
\text { Dh }=1.09 \text { and } 1.49 \mathrm{~mm}\end{array}$ & Air-water & $\begin{array}{l}\text { Bubbly, slug, churn, } \\
\text { slug-annular, annular }\end{array}$ \\
\hline Zhao dan $\mathrm{Bi}[2]$ & $\begin{array}{l}\text { Equilateral Triangular } \\
\mathrm{Dh}=2.886,1.443 \text { and } 0.866 \mathrm{~mm}\end{array}$ & Air-water & Bubbly, Taylor, churn, annular \\
\hline Hassan et al., [4] & $\begin{array}{l}\text { Circular } \\
\text { Dc }=800 \mu \mathrm{m}, 1 \text { and } 3 \mathrm{~mm}\end{array}$ & Air-water & $\begin{array}{l}\text { Surface tension dominated: } \\
\text { bubbly, intermittent; } \\
\text { Inertia dominated: churn, } \\
\text { annular }\end{array}$ \\
\hline Lee dan Lee [5] & $\begin{array}{l}\text { Circular } \\
\text { Dc }=1.46,1.8 \text {, and } 2 \mathrm{~mm}\end{array}$ & $\begin{array}{l}\text { Air-water, Air- } \\
\text { methanol }\end{array}$ & $\begin{array}{l}\text { Plug, slug, annular, rivulet, } \\
\text { stratified }\end{array}$ \\
\hline $\begin{array}{l}\text { Hanafizadeh et al., } \\
\text { [6] }\end{array}$ & $\begin{array}{l}\text { Circular } \\
\mathrm{Dc}=2,3, \text { and } 4 \mathrm{~mm}\end{array}$ & Air-water & $\begin{array}{l}\text { Bubbly, bubbly-slug, slug, } \\
\text { messy-slug, churn, wispy } \\
\text { annular, ring, wavy-annular, } \\
\text { annular }\end{array}$ \\
\hline Serizawa et al., [7] & $\begin{array}{l}\text { Circular } \\
\text { Dc }=20,25,50, \text { and } 100 \mu \mathrm{m}\end{array}$ & $\begin{array}{l}\text { Air-water } \\
\text { Steam-water }\end{array}$ & $\begin{array}{l}\text { Bubbly, slug, liquid-ring, } \\
\text { liquid-lump, annular }\end{array}$ \\
\hline Kawahara et al., [1] & $\begin{array}{l}\text { Circular } \\
\text { Dc }=100 \mu \mathrm{m}\end{array}$ & Nitrogen-water & $\begin{array}{l}\text { Slug-ring, ring-slug, } \\
\text { semi-annular, multiple flow }\end{array}$ \\
\hline Chung dan Kawaji [8] & $\begin{array}{l}\text { Circular } \\
\text { Dc }=50,100,250, \text { and } 530 \mu \mathrm{m}\end{array}$ & Nitrogen-water & $\begin{array}{l}\text { Bubbly, slug, churn, } \\
\text { slug-annular, annular }\end{array}$ \\
\hline $\begin{array}{l}\text { Saisorn and } \\
\text { Wongwises [9] }\end{array}$ & $\begin{array}{l}\text { Circular } \\
\text { Dc }=150 \mu \mathrm{m}\end{array}$ & Air-water & $\begin{array}{l}\text { Liquid-alone, throat-annular, } \\
\text { serpentine-like gas core } \\
\text { dan annular }\end{array}$ \\
\hline Sudarja et al., [10] & $\begin{array}{l}\text { Circular } \\
\mathrm{Dc}=1.6 \mathrm{~mm}\end{array}$ & Air-water & $\begin{array}{l}\text { Bubbly, plug, churn, } \\
\text { slug-annular, annular }\end{array}$ \\
\hline
\end{tabular}

Flow pattern, void fraction, and pressure gradient are the primary characteristic of two-phase flow. The main variables affecting the two-phase flow characteristic are superficial gas velocity, liquid superficial velocity, liquid viscosity, and liquid surface tension. The effects of liquid viscosity have been investigated by some authors, and the results are shown in Table 2 [11-18].

The effects of liquid surface tension on two-phase flow parameters were studied by Krishnamurthy and Peles [19] and Sadatomi et al., [20]. Krishnamurthy and Peles [19] reported their study on two-phase flow across a bank of $100 \mu \mathrm{m}$ diameter staggered circular micropillars, $100 \mu \mathrm{m}$ long with a pitch-to-diameter ratio of 1.5. They used ethanol for the liquid working fluid and the Reynolds number between 5 and 50 . The experimental results were compared to those of using water. The flow pattern map showed that the flow regimes were similar for the two liquids. However, there were some discrepancies in the transition lines. There was no significant effect of surface tension on the void fraction, while it significantly affected the pressure drop characteristics. Sadatomi et al., [20] conducted experimental studies on the effects of pipe diameter and liquid surface tension on the flow characteristics. They used 3, 5, and 9-mm inner diameter and employed four liquids with different surface tension. The experiment results concluded that the pipe diameter and liquid surface tension strongly affected the transition line, and the liquid surface tension did not significantly affect the frictional pressure drop but strongly affected the interfacial friction force and void fraction. 
Table 2

Studies of the effect of liquid viscosity on the two-phase flow characteristics

\begin{tabular}{|c|c|c|c|}
\hline Authors & Channel configurations & Working Fluids & Major finding \\
\hline $\begin{array}{l}\text { Fukano and } \\
\text { Furukawa [11] }\end{array}$ & $\begin{array}{l}\text { Circular } \\
\text { Dc }=26 \mathrm{~mm} \text {, vertical }\end{array}$ & $\begin{array}{l}\text { Air-glycerol } \\
\text { solution }\end{array}$ & $\begin{array}{l}\text { For annular flow, the interfacial } \\
\text { structure was strongly } \\
\text { influenced by the liquid } \\
\text { viscosity. }\end{array}$ \\
\hline Furukawa and & Circular & Air-aqueous & Liquid viscosity strongly \\
\hline Fukano [12] & $\begin{array}{l}\mathrm{Dc}=19.2 \mathrm{~mm}, 5.4 \mathrm{~m} \text { length, } \\
\text { vertical }\end{array}$ & glycerol solution & affected the flow patterns. \\
\hline $\begin{array}{l}\text { Matsubara and Naito } \\
\text { [13] }\end{array}$ & $\begin{array}{l}\text { Circular } \\
\text { Dc }=20 \mathrm{~mm} \text {, horizontal }\end{array}$ & $\begin{array}{l}\text { Air-aqueous } \\
\text { solution of } \\
\text { polysaccharide } \\
\text { thickener }\end{array}$ & $\begin{array}{l}\text { As the liquid velocity increased, } \\
\text { the regions of roll wave flow } \\
\text { and stratified flow were } \\
\text { replaced by that of annular and } \\
\text { annular flow and intermittent } \\
\text { flow }\end{array}$ \\
\hline $\begin{array}{l}\text { McNeil and Stuart } \\
{[14]}\end{array}$ & $\begin{array}{l}\text { Circular } \\
\text { Dc }=10 \mathrm{~mm} \text {, vertical }\end{array}$ & $\begin{array}{l}\text { Air-glycerin } \\
\text { solution }\end{array}$ & $\begin{array}{l}\text { The main flow was annular up- } \\
\text { flow. The data were } \\
\text { inconsistent with the annular } \\
\text { flow model }\end{array}$ \\
\hline Zhao et al., [15] & $\begin{array}{l}\text { Circular } \\
\text { Dc = } 26 \mathrm{~mm}, 5.5 \mathrm{~m} \text { long, } \\
\text { horizontal }\end{array}$ & Air-oil & $\begin{array}{l}\text { There were significant } \\
\text { discrepancies between low and } \\
\text { high viscosity liquid and gas } \\
\text { flows. }\end{array}$ \\
\hline Sudarja et al., [16] & $\begin{array}{l}\text { Circular } \\
\text { Dc }=1.6 \mathrm{~mm}\end{array}$ & $\begin{array}{l}\text { Air- glycerol-aqua } \\
\text { solution }\end{array}$ & $\begin{array}{l}\text { Liquid viscosity influenced the } \\
\text { shift of the transition line } \\
\text { between flow patterns in the } \\
\text { flow pattern map }\end{array}$ \\
\hline $\begin{array}{l}\text { Sukamta and Sudarja } \\
\text { [17] }\end{array}$ & $\begin{array}{l}\text { Circular } \\
\text { Dc }=1.6 \mathrm{~mm}\end{array}$ & $\begin{array}{l}\text { Air- glycerol-aqua } \\
\text { solution }\end{array}$ & $\begin{array}{l}\text { The higher liquid viscosity led to } \\
\text { an increase in the two-phase } \\
\text { flow pressure gradient }\end{array}$ \\
\hline Sukamta et al., [18] & $\begin{array}{l}\text { Circular } \\
\text { Dc }=1.6 \mathrm{~mm}\end{array}$ & $\begin{array}{l}\text { Air-pure water and } \\
\text { glycerin with } \\
\text { concentrations of } \\
40,50,60 \text {, and } \\
70 \%\end{array}$ & $\begin{array}{l}\text { The void fraction for plug flow } \\
\text { tended to be close to } 1 \text {. For the } \\
\text { churn flow pattern, the void } \\
\text { fraction fluctuated with a } \\
\text { moderate value. }\end{array}$ \\
\hline
\end{tabular}

Beside experimental, some studies carried-out by modeling. Balthazar and Majeed [22] performed a comparison between experiment and simulation data of two-phase heat transfer coefficient and pressure drop of horizontal evaporator refrigeration system using ammonia as refrigerant. The mass fluxes were 50 to $150 \mathrm{~kg} / \mathrm{s} \cdot \mathrm{m}^{2}$. As a result, the pressure drops and two-phase heat transfer coefficient discrepancies between experiment and simulation were $3.52 \%$ and $5.5 \%$, respectively. Sukamta [21] also compared the experiment versus modelling data of two-phase flow patterns using air and solution mixture of water and glycerine. The result shows a good agreement between experiment and simulation, especially for slug-annular, annular and churn flow patterns. AlAzawy et al., [23] used Star-CCM+ software on CFD technique to solve the three dimensional, steady, laminar and non-Newtonian Carreau model blood flow through a stenosis artery. The shape of stenosis was a trapezoidal with $70 \%$ and $90 \%$ blockage. They concluded that the levels of recirculation areas and vorticity are showed to be enlarged in the Carreau model compared with the case of Newtonian. 
The above explanation shows that no researcher has carried out the experiment and discussed the effects of liquid surface tension on two-phase flow in mini or microchannel in an inclined orientation. Therefore, a study on the effects of liquid surface tension on the gas-liquid two-phase flow pattern in a $30^{\circ}$ inclined capillary pipe is significant to be carried-out experimentally.

\section{Methodology}

Gas and liquid were employed as working fluids in the present study. Dry air was used as the gas fluid, while a mixture solution of distilled water and $3 \%$ butanol was employed as liquid fluid. The addition of butanol aimed to reduce the liquid surface tension. The surface tension of water was 71 millinewtons/meter $(\mathrm{mN} / \mathrm{m})$, while that of butanol was $24.37 \mathrm{mN} / \mathrm{m}$, and the mixture solution of water and $3 \%$ butanol was $42.9 \mathrm{mN} / \mathrm{m}$. The experimental rig used in the present study is demonstrated schematically in Figure 1, as previously used and reported by Sudarja et al., [16]. A 1.6 $\mathrm{mm}$ inner diameter glass pipe with a length of $130 \mathrm{~mm}$ was employed as a test section. The experimental apparatus was also equipped with an optical correction box, mixer, liquid flow meter, gas flow meter, camera, pressure transducer, data acquisition, and computer. The optical correction box aimed to eliminate the pipe surface curve effect. Perpendicular entrance type mixer was used to mix both gas and liquid phase working fluid before the test section. The mixer consisted of a mixing chamber where two phases met and a converging zone where the flow patterns developed.

The liquid flow meter used in the study was from Omega and TOKYO KEISO, with an accuracy of $\pm 5 \%$ and $\pm 3 \%$, respectively. Nikon J4 high-speed video camera with a $1200 \mathrm{fps}$ speed and a $640 \mathrm{x}$ 480-pixel resolution was employed to capture the flow images. Dwyer's pressure transducer, which coupled with Advantech data acquisition, was used to measure the pressure drop along the test section. Ranges of gas and liquid superficial velocities were $0.025-66.3 \mathrm{~m} / \mathrm{s}$ and $0.033-4.935 \mathrm{~m} / \mathrm{s}$, respectively. The experiment was conducted in adiabatic conditions. The flow patterns were obtained from the flow video images, while the void fraction was obtained from image processing.

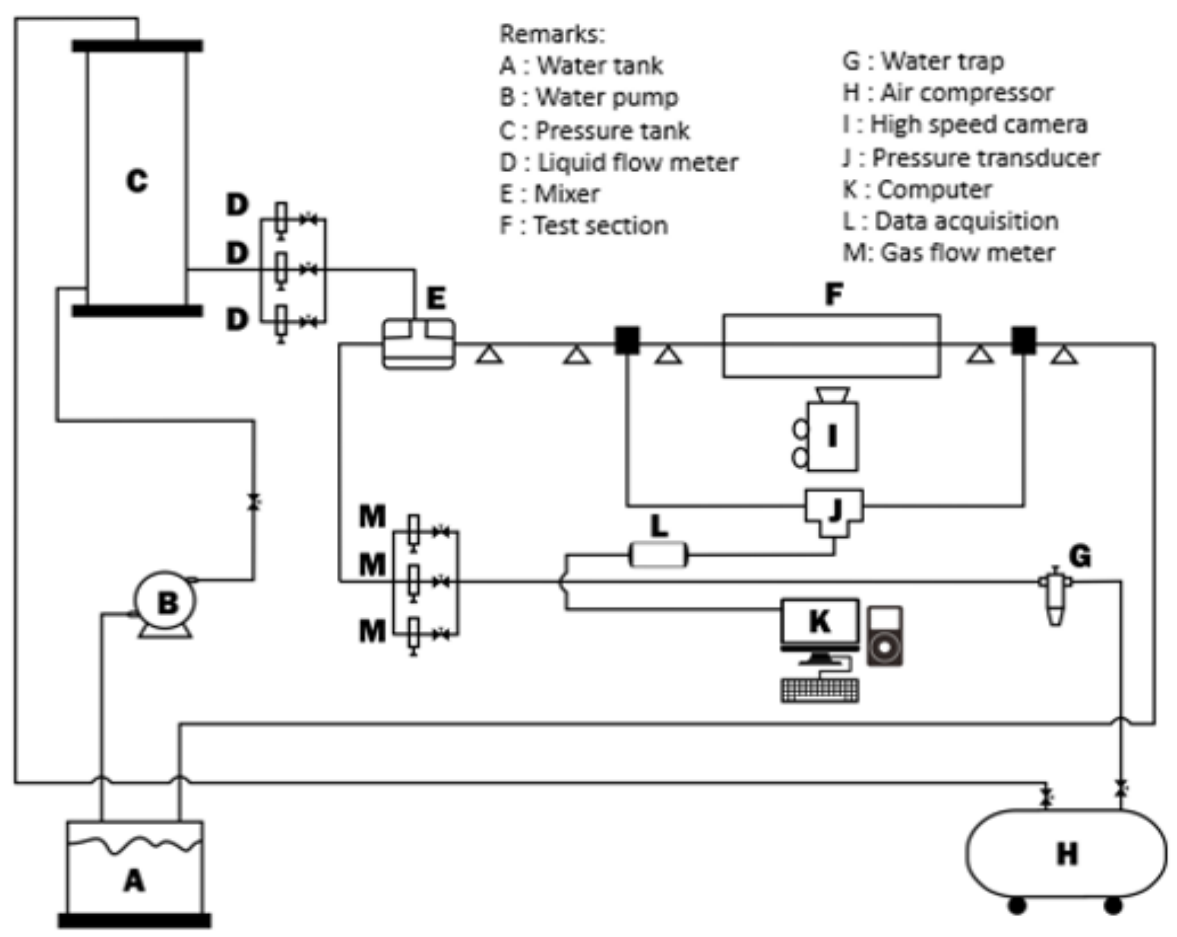

Fig. 1. Schematic diagram of experimental apparatus 


\section{Results}

\subsection{Flow Pattern and Void Fraction}

Annular, bubbly, churn, plug, and slug-annular flow patterns occurred in the present study. Meanwhile, the separated flow (or sometimes called stratified flow) was not observed. It was indicated that the surface tension effect was more dominant than the gravitation. The explanation of each flow regime and its void fraction is given below.

\subsubsection{Plug flow}

In terms of flow pattern and void fraction, the characteristics of plug flow are shown in Figure 2 and Figure 3. Plug flow is characterized by the intermittent flow of gas plug and water bridge. It occurred at low of both $\mathrm{J}_{\mathrm{G}}$ and $\mathrm{J}_{\mathrm{L}}$, and at moderate $\mathrm{J}_{\mathrm{G}}$ with low to moderate $\mathrm{J}_{\mathrm{L}}$. This condition is in line with those reported by Sudarja et al., [10]. Figure 1 and Figure 2 present that the superficial velocity of gas $\left(J_{G}\right)$ strongly affects the plug length; here, the higher the $J_{G}$, the longer the gas plug. This condition was also stated previously by Saisorn and Wongwises [9] and Sudarja et al., [10]. The void fraction time series depicts that the plug diameter is the same as the pipe's inner diameter, indicated by the magnitude of the void fraction equal to 1 . It is also confirmed with the PDF, dominant in the value of 1 and 0 , in which 0 means water bridge flow, and 1 is the body of the plug. The void fraction values between 0 and 1 are the nose and tail of the plug.
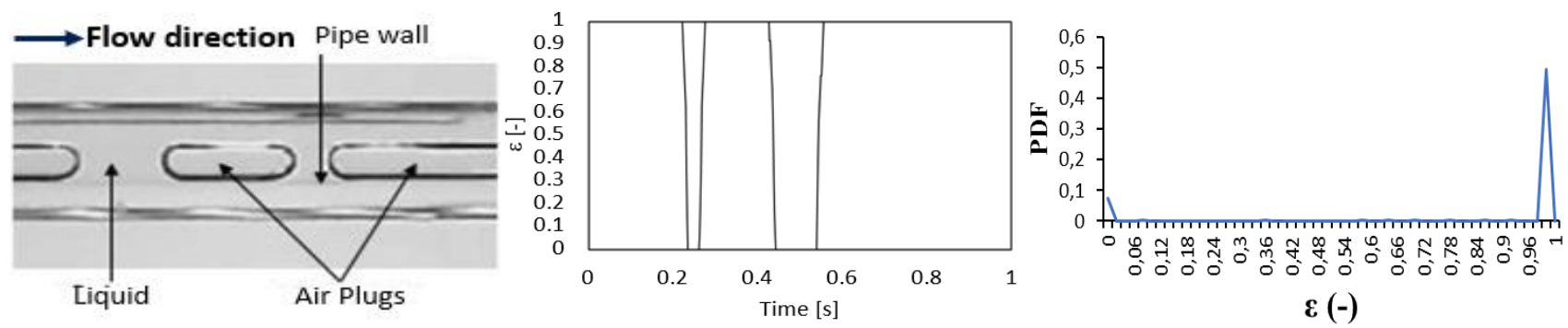

Fig. 2. Flow pattern, void fraction, and PDF of plug flow at $J_{G}=0.066 \mathrm{~m} / \mathrm{s}$ and $J_{L}=0.149 \mathrm{~m} / \mathrm{s}$
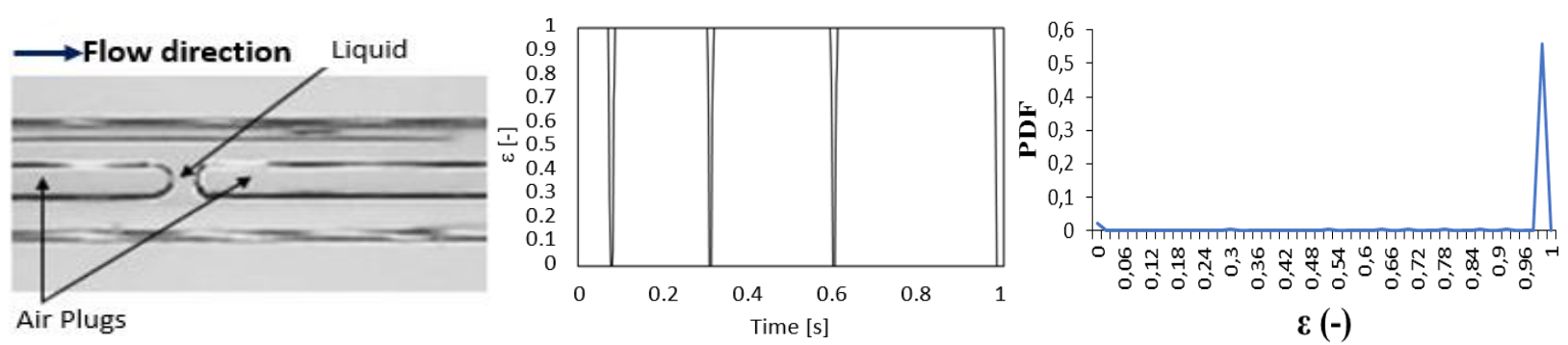

Fig. 3. Flow pattern, void fraction, and PDF of plug flow at $J_{G}=0.207 \mathrm{~m} / \mathrm{s}$ and $\mathrm{J}_{\mathrm{L}}=0.149 \mathrm{~m} / \mathrm{s}$

\subsubsection{Bubbly flow}

The bubbly flow pattern occurs at very low $J_{G}$ and high $J_{L}$. The bubbly flow in the present experiment is not a single flow but a mixed flow because sometimes a long plug appears and is followed by dispersed bubbles. Flow pattern and void fraction of bubbly flow is depicted in Figure 4 and Figure 5, consisting of flow image, time series of void fraction, and PDF of void fraction. From the void fraction time-series graph, it is seen that the magnitude of the void fraction is low, indicating no bubble with a diameter the same as the channel diameter. The void fraction PDF shows a dominant 
value of 0 , meaning that the liquid flow is dominant. When $J_{G}$ is raised $(0.066 \mathrm{~m} / \mathrm{s}$ to $0.116 \mathrm{~m} / \mathrm{s})$, the bubble size becomes bigger and water dominance decreases (0.18 to 0.16$)$.
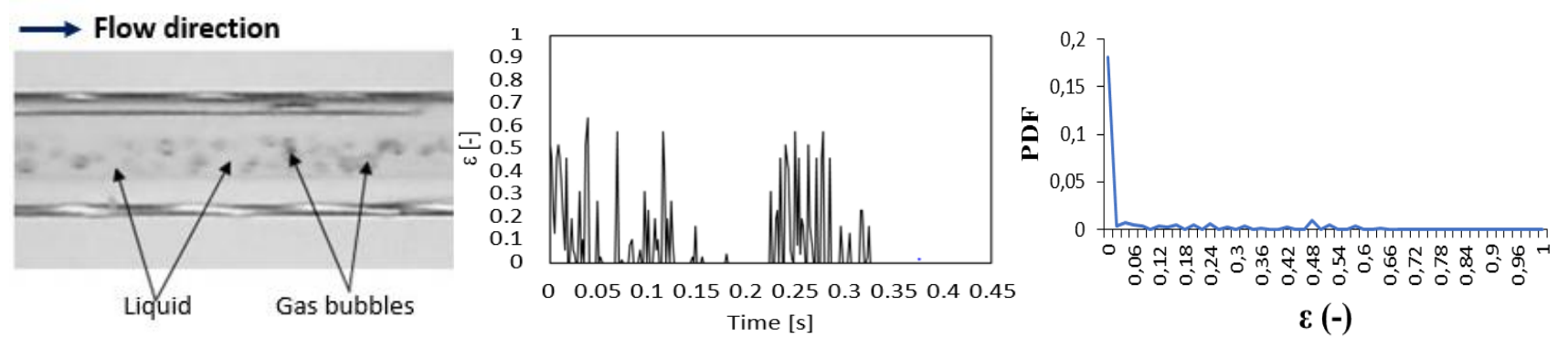

Fig. 4. Flow pattern, void fraction, and PDF of bubbly flow at $J_{G}=0.066 \mathrm{~m} / \mathrm{s}$ and $\mathrm{J}_{\mathrm{L}}=2.297 \mathrm{~m} / \mathrm{s}$
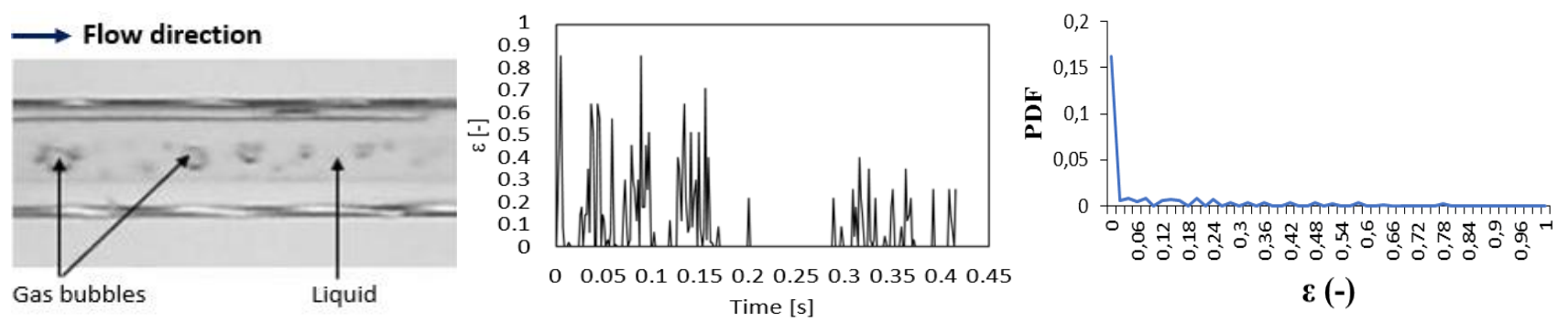

Fig. 5. Flow pattern, void fraction, and PDF of bubbly flow at $J_{G}=0.116 \mathrm{~m} / \mathrm{s}$ and $J_{L}=2.297 \mathrm{~m} / \mathrm{s}$

\subsubsection{Slug-annular flow}

At high $J_{G}$ and low $J_{L}$, the flow pattern is slug-annular. Slug-annular flow is formed from plug flow when the $J_{G}$ is increased. At certain $J_{G}$, the gas pushes and pierces the liquid bridge. The gas forms gas core flow in the center of the channel, while the liquid forms liquid film flow at the pipe wall. In some points, the liquid films are thicker than other points and form the liquid neck. Hence, the characteristic of slug-annular flow is the appearance of liquid necks. Figure 6 and Figure 7 show the effect of increasing $\mathrm{J}_{\mathrm{L}}$. The void fraction time-series graph shows that the void fraction is lower when $\mathrm{JL}$ is increased. It can also be confirmed that the peak frequency is shifted to the lower void fraction when the $\mathrm{JL}$ increases.
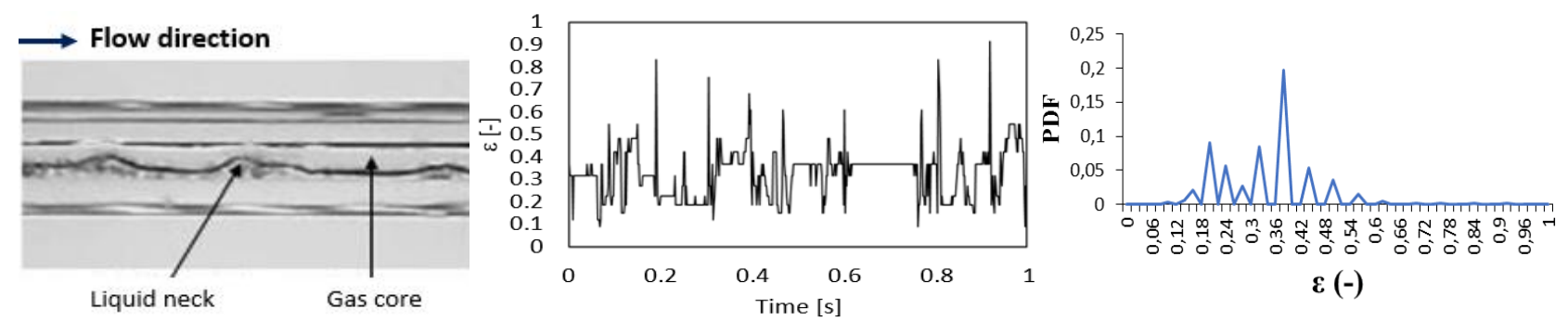

Fig. 6. Flow pattern, void fraction, and PDF of slug-annular flow at $\mathrm{J}_{\mathrm{G}}=3 \mathrm{~m} / \mathrm{s}$ and $\mathrm{J}_{\mathrm{L}}=0.0091 \mathrm{~m} / \mathrm{s}$ 

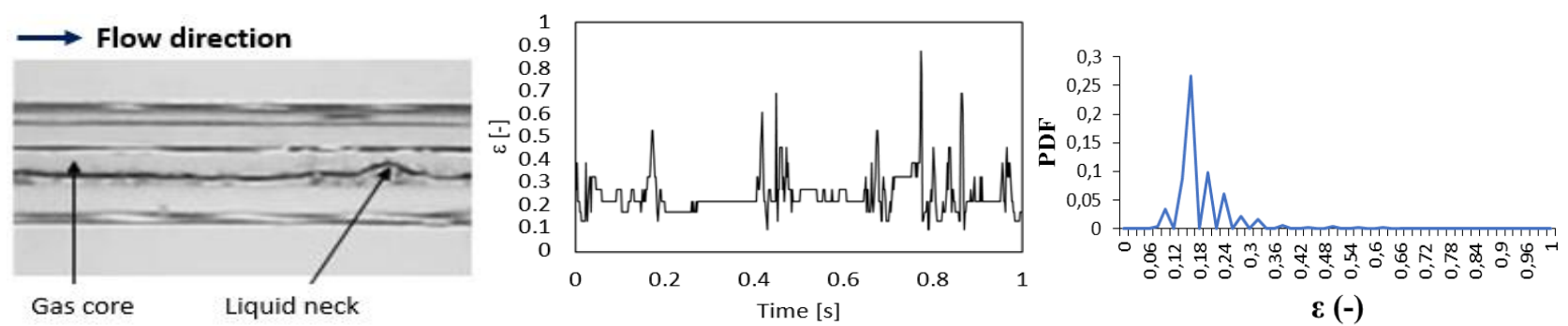

Fig. 7. Flow pattern, void fraction, and PDF of slug-annular flow at $J_{G}=3 \mathrm{~m} / \mathrm{s}$ and $\mathrm{J}_{\mathrm{L}}=0.033 \mathrm{~m} / \mathrm{s}$

\subsubsection{Annular flow}

Annular flow or sometimes called ring flow, occurs at high $\mathrm{J}_{\mathrm{G}}$ and low $\mathrm{J}_{\mathrm{L}}$. As shown in Figure 8 and Figure 9, annular flow consists of gas core and liquid film. From the flow pattern configuration, it can be seen that the increase of $J_{L}$ causes the thicker liquid film. Conversely, the higher $J_{G}$, the thinner the liquid film. The increasing $J_{L}$ also causes higher ripples at the flow interface. Meanwhile, from the void fraction time-series graph and the PDF, increasing $J_{L}$ causes a lower void fraction and spreads wider. It indicates that the void fraction is in higher fluctuation at higher $\mathrm{J}_{\mathrm{L}}$.

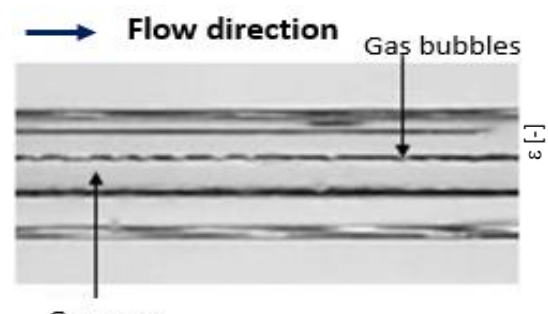

Gas core

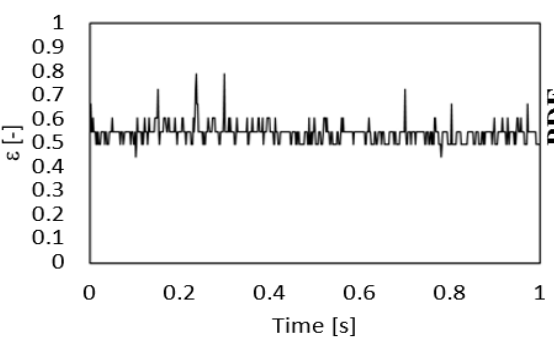

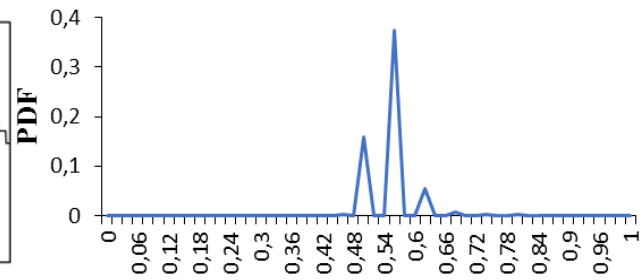

$\varepsilon(-)$

Fig. 8. Flow pattern, void fraction, and PDF of annular flow at $J_{G}=50 \mathrm{~m} / \mathrm{s}$ and $\mathrm{J}_{\mathrm{L}}=0.033 \mathrm{~m} / \mathrm{s}$
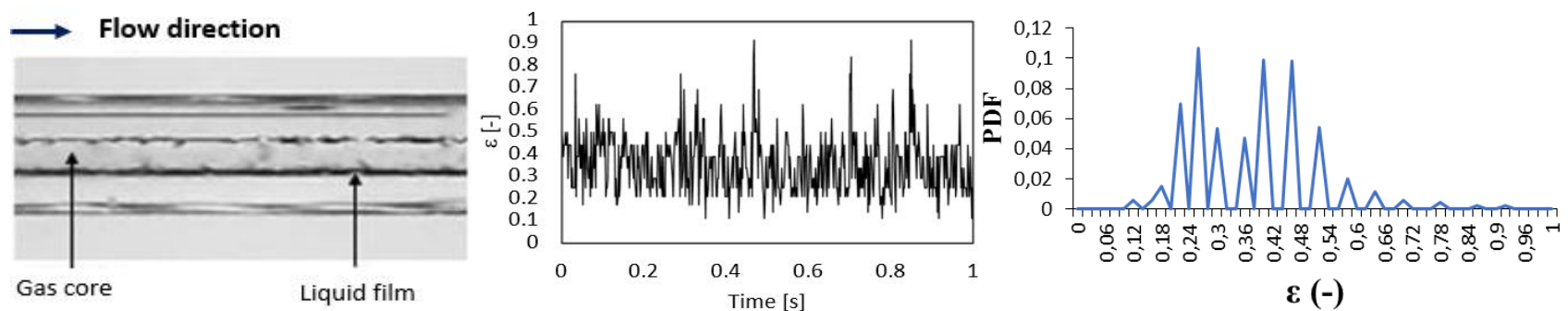

Fig. 9. Flow pattern, void fraction, and PDF of annular flow at $J_{G}=50 \mathrm{~m} / \mathrm{s}$ and $J_{L}=0.091 \mathrm{~m} / \mathrm{s}$

\subsubsection{Churn flow}

Churn flow is obtained at a high of both $\mathrm{J}_{\mathrm{G}}$ and $\mathrm{J}_{\mathrm{L}}$. Some disruptive regions appear, as depicted in Figure 10 and Figure 11. It is caused by the turbulence and mixture flow of liquid and gas. As shown in those figures, higher $J_{L}$ implies a more disruptive area, and darker appears. In terms of void fraction, increasing $J_{L}$ tends to lower void fraction. From the PDF, it is seen that the peak of the frequency shifts to the left side, or in other words, it shifts to the lower value of the void fraction. 

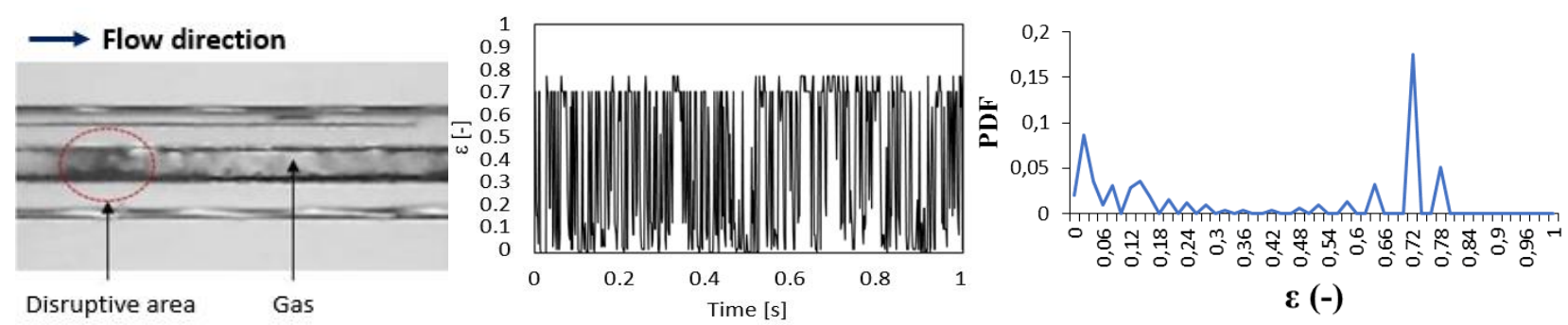

Fig. 10. Flow pattern, void fraction, and PDF of churn flow at $J_{G}=22.6 \mathrm{~m} / \mathrm{s}$ and $J_{L}=0.539 \mathrm{~m} / \mathrm{s}$
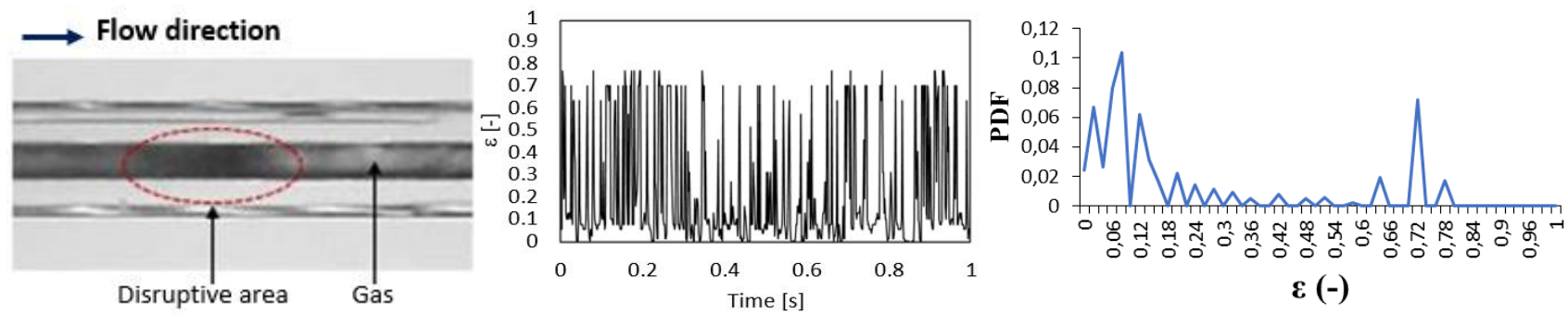

Fig. 11. Flow pattern, void fraction, and PDF of churn flow at $J_{G}=22.6 \mathrm{~m} / \mathrm{s}$ and $J_{L}=0.7 \mathrm{~m} / \mathrm{s}$

\subsection{Flow Pattern Map}

The flow pattern map is plotted in horizontal and vertical axes, superficial velocities gas and liquid. Both axes are stated on a logarithmic scale. It is intended to cover a wide range of both $\mathrm{J}_{\mathrm{G}}$ and $\mathrm{J}_{\mathrm{L}}$. The ranges of $J_{G}$ and $J_{L}$ are $0.025-66.3 \mathrm{~m} / \mathrm{s}$ and $0.033-4.935 \mathrm{~m} / \mathrm{s}$, respectively. The flow pattern map of the present study is shown in Figure 12, demonstrating that the plug and churn flow regimes occupy the widest area. Figure 12 can be used to predict the flow pattern which occurs at any couple of both $J_{G}$ and $J_{L}$ for any fluid with the properties same as or like the present working fluids.

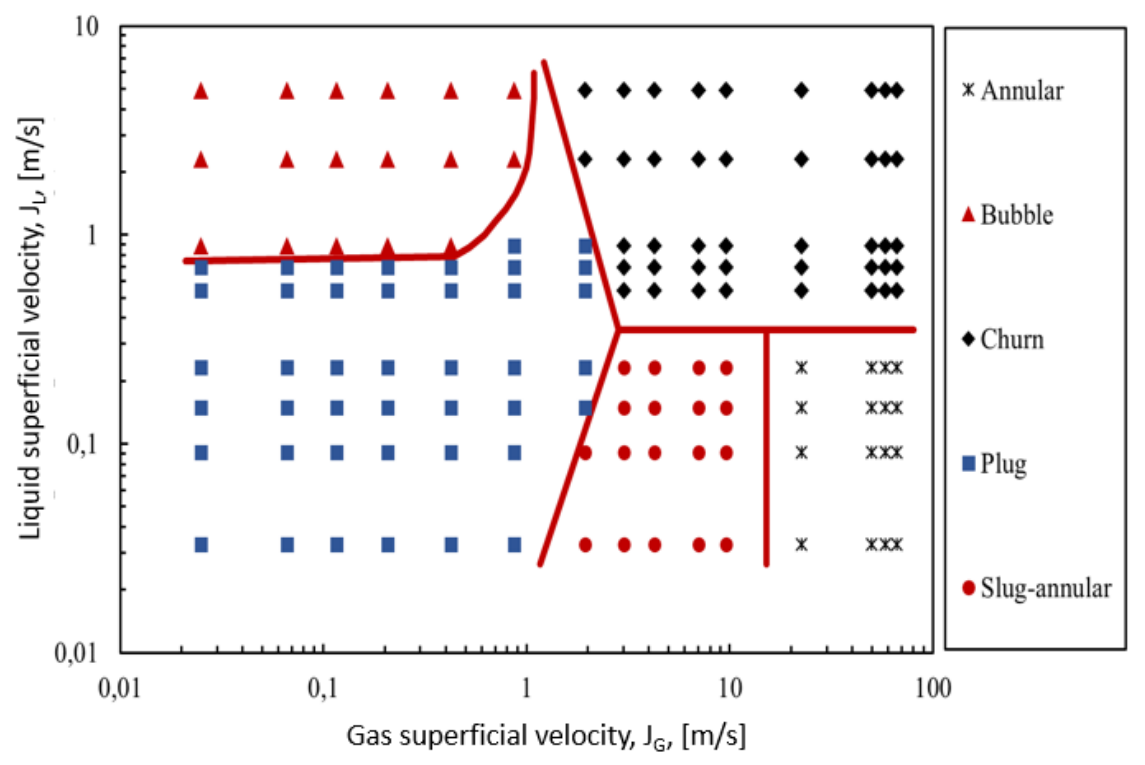

Fig. 12. Flow pattern map of B3 gas-liquid two-phase flow

The map is then compared to other experimental results proposed by previous researchers, Triplett et al., [3] and Chung and Kawaji [8], which used water (higher surface tension] as the liquid working fluid, as shown in Figure 13. In terms of the type of flow patterns observed, all are in good agreement. However, concerning the transition lines, there are some discrepancies. The transition 
line between slug-annular and annular against churn flow is shifted to the lower side or the lower $\mathrm{J}_{\mathrm{L}}$ when the liquid surface tension decreases. It means that the churn flow area is wider, or in other words, the churn flow can be easily formed when the liquid surface tension is lower. This condition is the implication of the high turbulence of both fluids. This comparison strengthens the previous studies which stated that channel size, working fluid properties (viscosity and surface tension) are very sensitive to affect the boundary transition lines.

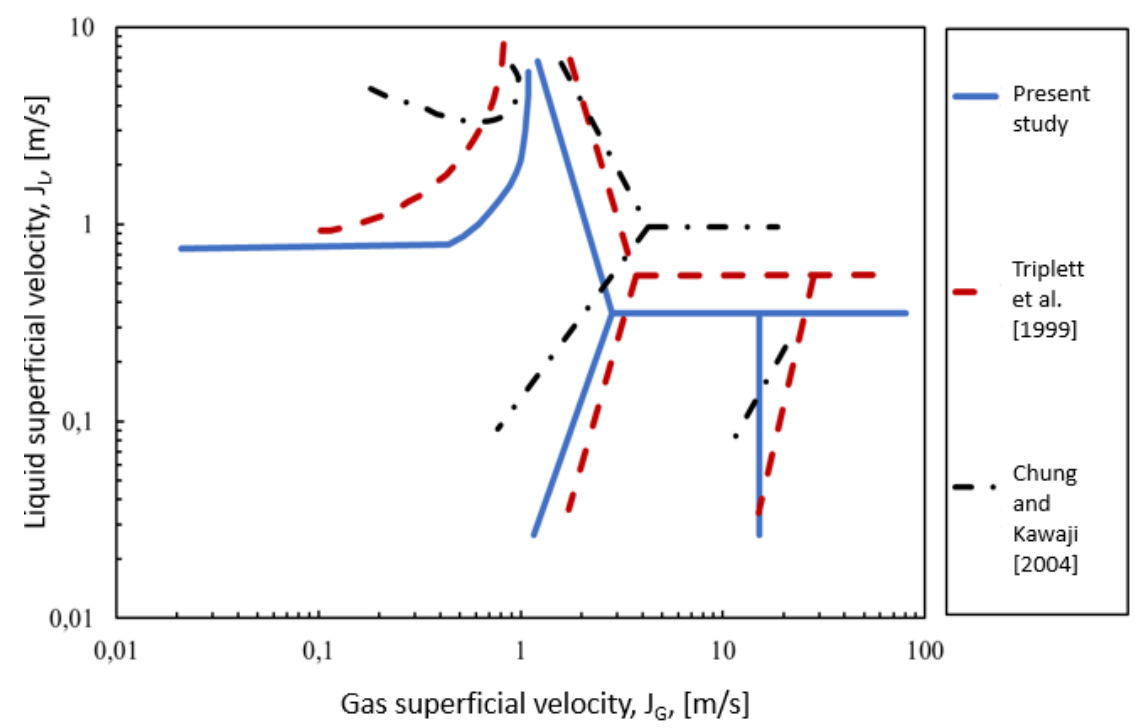

Fig. 13. Flow pattern map comparison between present and the previous studies

\section{Conclusions}

The experimental research on the gas-liquid two-phase flow pattern and void fraction in the mini channel using low surface tension liquid in adiabatic condition was performed. The ranges of gas and liquid superficial velocities were $0.025-66.3 \mathrm{~m} / \mathrm{s}$ and $0.033-4.935 \mathrm{~m} / \mathrm{s}$. The liquid was the water and butanol solution with a percentage of $3 \%$, while the gas phase was dry air. The results and discussion lead to the following conclusions

i. Annular, bubbly, churn, plug and slug-annular flow patterns occurred in the present study; meanwhile, the separated flow was not observed.

ii. The bubbly flow observed in the present study was dispersed bubbly.

iii. Both gas and liquid superficial velocities influenced the flow configuration of the flow and its void fraction.

iv. The transition line between slug-annular and annular against churn flow was shifted to the lower side or toward the lower $J_{L}$ when the liquid surface tension decreased, meaning that the churn flow could be easily formed when the liquid surface tension was lower.

\section{Acknowledgment}

The authors would like to express their appreciation to LP3M of Universitas Muhammadiyah Yogyakarta for funding this research. 


\section{References}

[1] Kawahara, A., PM-Y. Chung, and M. Kawaji. "Investigation of two-phase flow pattern, void fraction and pressure drop in a microchannel." International Journal of Multiphase Flow 28, no. 9 (2002): 1411-1435. https://doi.org/10.1016/S0301-9322(02)00037-X

[2] Zhao, T. S., and Q. C. Bi. "Co-current air-water two-phase flow patterns in vertical triangular microchannels." International Journal of Multiphase Flow 27, no. 5 (2001): 765-782. https://doi.org/10.1016/S0301-9322(00)00051$\underline{3}$

[3] Triplett, Ka A., S. M. Ghiaasiaan, S. I. Abdel-Khalik, and D. L. Sadowski. "Gas-liquid two-phase flow in microchannels Part I: two-phase flow patterns." International Journal of Multiphase Flow 25, no. 3 (1999): 377-394. https://doi.org/10.1016/S0301-9322(98)00054-8

[4] Hassan, I., M. Vaillancourt, and K. Pehlivan. "Two-phase flow regime transitions in microchannels: a comparative experimental study." Microscale Thermophysical Engineering 9, no. 2 (2005): 165-182. https://doi.org/10.1080/10893950590945049

[5] Lee, Chi Young, and Sang Yong Lee. "Influence of surface wettability on transition of two-phase flow pattern in round mini-channels." International Journal of Multiphase Flow 34, no. 7 (2008): 706-711. https://doi.org/10.1016/i.ijmultiphaseflow.2008.01.002

[6] Hanafizadeh, P., M. H. Saidi, A. Nouri Gheimasi, and S. Ghanbarzadeh. "Experimental investigation of air-water, two-phase flow regimes in vertical mini pipe." Scientia Iranica 18, no. 4 (2011): 923-929. https://doi.org/10.1016/j.scient.2011.07.003

[7] Serizawa, Akimi, Ziping Feng, and Zensaku Kawara. "Two-phase flow in microchannels." Experimental Thermal and Fluid Science 26, no. 6-7 (2002): 703-714. https://doi.org/10.1016/S0894-1777(02)00175-9

[8] Chung, PM-Y., and M. Kawaji. "The effect of channel diameter on adiabatic two-phase flow characteristics in microchannels." International Journal of Multiphase Flow 30, no. 7-8 (2004): 735-761. https://doi.org/10.1016/j.ijmultiphaseflow.2004.05.002

[9] Saisorn, Sira, and Somchai Wongwises. "Flow pattern, void fraction and pressure drop of two-phase air-water flow in a horizontal circular micro-channel." Experimental Thermal and Fluid Science 32, no. 3 (2008): 748-760. https://doi.org/10.1016/j.expthermflusci.2007.09.005

[10] Sudarja, Aqli Haq, Deendarlianto, Indarto, and Adhika Widyaparaga. "Experimental study on the flow pattern and pressure gradient of air-water two-phase flow in a horizontal circular mini-channel." Journal of Hydrodynamics 31 , no. 1 (2019): 102-116. https://doi.org/10.1007/s42241-018-0126-2

[11] Fukano, T., and T. Furukawa. "Prediction of the effects of liquid viscosity on interfacial shear stress and frictional pressure drop in vertical upward gas-liquid annular flow." International Journal of Multiphase Flow 24, no. 4 (1998): 587-603. https://doi.org/10.1016/S0301-9322(97)00070-0

[12] Furukawa, T., and T. Fukano. "Effects of liquid viscosity on flow patterns in vertical upward gas-liquid two-phase flow." International Journal of Multiphase Flow 27, no. 6 (2001): 1109-1126. https://doi.org/10.1016/S03019322(00)00066-5

[13] Matsubara, Hiroaki, and Kiyoshi Naito. "Effect of liquid viscosity on flow patterns of gas-liquid two-phase flow in a horizontal pipe." International Journal of Multiphase Flow 37, no. 10 (2011): 1277-1281. https://doi.org/10.1016/i.ijmultiphaseflow.2011.08.001

[14] McNeil, David A., and Alastair D. Stuart. "The effects of a highly viscous liquid phase on vertically upward two-phase flow in a pipe." International Journal of Multiphase Flow 29, no. 9 (2003): 1523-1549. https://doi.org/10.1016/S0301-9322(03)00122-8

[15] Zhao, Y., H. Yeung, E. E. Zorgani, A. E. Archibong, and L. Lao. "High viscosity effects on characteristics of oil and gas two-phase flow in horizontal pipes." Chemical Engineering Science 95 (2013): 343-352. https://doi.org/10.1016/i.ces.2013.03.004

[16] Sudarja, Sukamta, Deendarlianto, and Indarto. "The Effect of Liquid Viscosity on The Gas-Liquid Two-Phase Flow Pattern in $45^{\circ}$ Inclined Capillary Pipe." Journal of Advanced Research in Fluid Mechanics and Thermal Sciences 75, no. 1 (2020): 48-57. https://doi.org/10.37934/arfmts.75.1.4857

[17] Sukamta, and Sudarja. "The Significant Effect of Liquid Viscosity on Two-Phase Flow Pressure Gradient in Mini Channel with Slope of $15^{\circ}$ against Horizontal." Journal of Advanced Research in Fluid Mechanics and Thermal Sciences 70, no. 2 (2020): 116-123. https://doi.org/10.37934/arfmts.70.2.116123

[18] Sukamta, Noviyanto, Sudarja, and Sri Sundari. "Characteristics of Void Fraction Using Image Processing of TwoPhase Flow of Air-Pure Water and Glycerin (40-70\%) on A Transparent Mini Pipe with Slope of $45^{\circ}$ to the Horizontal." Journal of Advanced Research in Experimental Fluid Mechanics and Heat Transfer 1, no. 1 (2020): 2937. 
[19] Krishnamurthy, Santosh, and Yoav Peles. "Surface tension effects on adiabatic gas-liquid flow across micro pillars." International Journal of Multiphase Flow 35, no. 1 (2009): 55-65. https://doi.org/10.1016/j.ijmultiphaseflow.2008.08.001

[20] Sadatomi, Michio, Akimaro Kawahara, Masatoshi Matsuo, and Katsuhiro Ishimura. "Effects of surface tension on two-phase gas-liquid flows in horizontal small diameter pipes." Journal of Power and Energy Systems 4, no. 2 (2010): 290-300. https://doi.org/10.1299/ipes.4.290

[21] Sukamta, Sukamta. "Computational fluid dynamics (CFD) and experimental study of two-phase flow patterns gasliquid with low viscosity in a horizontal capillary pipe." CFD Letters 11, no. 8 (2019): 16-23.

[22] Balthazar, Pravinth, and Muzathik Abdul Majeed. "Simulation analysis of two-phase heat transfer characteristics in a smooth horizontal ammonia (R717) evaporator tube." CFD Letters 10, no. 2 (2018): 49-58.

[23] Al-Azawy, Mohammed Ghalib, Saleem Khalefa Kadhim, and Azzam Sabah Hameed. "Newtonian and NonNewtonian Blood Rheology Inside a Model of Stenosis." CFD Letters 12, no. 11 (2020): 27-36. https://doi.org/10.37934/cfdl.12.11.2736 